\title{
AKUNTABILITAS DAN KAPABILITAS BANK SYARIAH (STUDI PADA BANK SYARIAH “X" CABANG MALANG)
}

\author{
Ahmad Fahrudin A \\ Fakultas Ekonomi,Universitas Islam Negeri Maulana Malik Ibrahim Malang \\ Jl. Gajayana 50 Malang Telp. 0341-551354 Faks. 0341-572533 \\ HP : 08123393789. e-mail : afahrudin.feuin@gmail.com/
}

\begin{abstract}
The dynamics of development of Islamic banking in the working area KBI Malang is encouraging its development in which the Islamic banks NPL rate tends to increase significantly. In this institution within a period of nearly two years alone have been able to make an investment of about $13 \mathrm{M}$. with clients (depositors) of about 1300 people and 250 customers (users). This is the kind of qualitative research that uses a case study, the approach aims to maintain the integrity of the object and also with verifikatif approach. Verifikatif approach is intended to minimize the possibility of low reliability is often the case in case study research, in order to explain: first: accountability factors in the management of Islamic banks and funds processing, collection and utilization of capital funds, second: factors capabilities of Islamic banks in improving the quality and quantity of social and economic life of society. The results showed that: Factors that support the assessment of accountability in the management of Islamic banks and funds processing, collection and utilization of capital funds is reviewed from the aspect of increased cash liquidity ratio of $15.06 \%$ in 2005 rose to $18.12 \%$ in 2006 so it has good title, while LDR $44.12 \%$, still well in the predicate. ROA profitability aspects seem to have decreased between 2005 to 2006, where in 2005 while the ROA of 1.99\% in 2006 to $0.77 \%$, to BOPO increase from the year 2005 amounted to $84.75 \%$ in 2006 amounting to $95.01 \%$, for capital aspects of healthy and performing said, because the CAR above 10\% which in 2005 grew 16.94\% to $19.07 \%$. Factors that support the capability of Islamic banks in improving the quality and quantity of social and economic life of society is: cooperation financing, business development and service cooperation, and cooperation through SME business support reached $42 \%$ this year.
\end{abstract}

Key word: Accountability, Capability, Islamic Banks

\section{PENDAHULUAN}

Keberadaan bank syariah di Indonesia merupakan sebuah kebutuhan mendesak untuk pembenahan ekonomi masyarakat Indonesia, khususnya umat Islam, setelah sistim ekonomi sosialisme Orde Lama dan kapitalisme-individualisme Orde Baru gagal membangun perekomian angsa Indonesia yang berpenduduk mayoritas umat Islam ini. Sejak diterbitkannya UU nomor 7/1992 dilanjutkan dengan UU nomor 10/1998, bank syariah terus bergulir laksana bola salju, kian tahun kian berkembang dan terus mendapatkan kepercayaan masyarakat. 
Bahkan, Surat Keputusan Direksi Bank Indonesia tanggal 12 Mei 1999, tentang Bank Umum, Bank Umum Berdasarkan Prinsip Syariah, Bank Perkeriditan Rakyat (BPR), dan BPR Berdasarkan Prinsip Syariah, semakin memperkuat dasar hukum eksistensi Bank Syariah di Indonesia. Banyak kalangan berharap, kehadiran bank syariah mampu mempercepat recovery ekonomi di Indonesia, seperti yang dialami Malaysia.

Menurut Adiwarman Karim, Pengamat perekonomian Syariat dan Direktur Eksekutif Muamalat Institute, Malaysia mampu mempercepat recovery ekonominya karena sejak 9 tahun sebelum terjadinya krisis di Asia, di Malaysia telah beridri Bank Syariah Malaysia Berhad (BSMB) yang mempunyai lebih dari 70 cabang yang tersebar hampir di seluruh negara bagiannya. Hal ini juga dibenarkan Aliyafie, Mantan Ketua Majelis Ulama Indonesia dan Pengawan Dewan Syariah Nasional. Bahkan, katanya lebih lanjut, di beberapa negara yang mempunyai sistem perbankan syariah, seperti Mesir, Siprus, Kuwait, Bahrain, Unit Emirat Arab, Iran, Turki dan Pakistan, tingkat ketahanan ekonominya lebih kuat (Media Akuntansi, 2000:8-9).

Sedangkan dinamika bank syari'ah bila dilihat dari dana pihak ketiga (DPK), yang berhasil dihimpun 11,88\% (s-t-s) atau sebesar 24,99\% (y-o-y) dari Rp 150 miliar pada posisi desember 2004 menjadi 168 miliar pada posisi juni 2005 dan pada posisi desember 2005 mencapai Rp 188 miliar. Sedangkan pembiayaan yang mampu disalurkan meningkat 6,53\% (st-s) atau sebesar 18,69\% (y-o-y) dari Rp 147 miliar pada Juni 2004 menjadi Rp 163 miliar pada semester I 2005 dan sebesar Rp. 174 muiliar pada posisi desember 2005. Sehingga tingkat Financing to Deposit Ratio (FDR), yakni proporsi antara pembiayaan terhadap dana yang berhasil dihimpun perbankan syari'ah pada posisi desember 2005 berada pada angka 92,55\% lebih tinggi pada LDR bank umum yang sebesar 60,55\%.

Gambaran ini dapat dijadikan sebuah hipotesa mengenai adanya potensi pengembangan perbankan syari'ah diwilayah kerja KBI Malang. Namun demikian dalam perkembangannya angka NPL bank umum syari'ah cenderung mengalami kenaikan yang signifikan. Pada posisi desember 2005 angka NPL berada pada angka 6,20\%, meningkat tajam bila dibandingkan NPL pada bulan desmber 2004 yang sebesar 0, 95\%. Untuk memperoleh gambaran yang lebih utuh terhadap dinamika perbankan syari'ah di Kota Malang dapat dilihat dalam tabel berikut : 
Tabel 1

Dinamika Bank Syari'ah Malang dilihat dari Dana Pihak Ketiga (DPK)

\begin{tabular}{|l|l|l|l|l|l|l|l|l|}
\hline & & \multicolumn{3}{|c|}{ Smt / Tahun (Juta Rp) } & \multicolumn{2}{l|}{ Perubahan s-t-s } & \multicolumn{2}{l|}{ Perubahan y-o-y } \\
\hline No & Keterangan & II/2004 & I/2005 & II/2005 & Nominal & Persen & Nominal & Persen \\
\hline 1 & Aset & 167.434 & 193.10 & 223.983 & 30.973 & 16.05 & 56.549 & 33.77 \\
\hline 2 & Dpk & 150.577 & 168 & 188.209 & 19.984 & 11.88 & 37.632 & 24.99 \\
& - Giro & 5.368 & 4.869 & 11.905 & 7.036 & 144.51 & 6.537 & 121.78 \\
& - Tabungan & 61.179 & 65.852 & 71.452 & 5.600 & 8.50 & 10.273 & 16.79 \\
& - Deposito & 84.030 & 97.504 & 104.852 & 7.348 & 7.54 & 20.822 & 24.78 \\
\hline 3 & Pembiayaan & 146.757 & 163.349 & 174.179 & 10.830 & 6.63 & 27.422 & 1869 \\
\hline 4 & NPL (\%) & 0.95 & 5.84 & 6.20 & & & & \\
\hline 5 & DR (\%) & 97.46 & 97.10 & 92.55 & & & & \\
\hline
\end{tabular}

Sumber : KBI Malang 2006 (diolah)

Kondisi seperti ini juga dirasakan oleh beberapa bank yang menerapkan sistem syariah di Indonesia, seperti Bank Syariah “ X” Indonesia. Di lembaga ini dalam jangka waktu hampir 2 tahun saja telah mampu meraup investasi sekitar 13 M. dengan nasabah (penabung) sekitar 1300 orang dan 250 nasabah (pengguna). Mengapa Bank Syariah " $X$ " Malang mendapatkan kepercayaan besar dari masyarakat di tengah krisis ekonomi? Bagaimana akuntabilitas dan kompetibilitasnya di tengah-tengah keberadaan bank konvensional yang jauh lebih lama berdirinya? Perlu penelitian yang dilakukan dengan tanggung jawab moral demi tercapainya banyak kalangan terhadap bank syariah pada umumnya.

\section{RUMUSAN MASALAH}

1. Faktor-faktor apa yang mendukung kompetibilitas bank syariah dalam meningkatkan kualitas dan kuantitas kehidupan sosial ekonomi masyarakat?

2. Faktor-faktor apa yang mendukung penilaian akuntabilitas bank syariah dalam manajemen dan pengolahan dana, pengumpulan modal dan pemanfaatan dana?

\section{TINJAUAN PUSTAKA}




\section{Penelitian Terdahulu}

Sekalipun dari segi hukum eksistensi bank syariah di Indonesia tidak diragukan lagi, akan tetapi masyarakat (muslim) Indonesia tidak banyak yang memahami seluk beluk bank Islam yang lahir pada hampir 9 tahun yang lalu ini. Pada tahun 1999 Wibisana dkk. mengadakan penelitian tentang "Persepsi Masyarakat terhadap Bank Syariah" yang memperlihatkan ketidakpahaman masyarakat terhadap bank syariah (Wibisana dkk, 1999). Kemudian setahun berikutnya, Triyuwono dkk. (2000) mengadakan penelitian lanjutan tentang "Potensi, Preferensi dan Perilaku Masyarakat terhadap Bank Syariah di Jawa Timur" dan menghasilkan sebuah kesimpulan bahwa $32 \%$ dari responden individual yang berjumlah 1500 dan $36 \%$ dari 150 responden perusahaan menyatakan berpreferensi pada bank syariah.

Dalam kesimpulan akhir penelitian Triyuwono dkk. yang disebutkan terakhir menyatakan bahwa keputusan untuk memilih atau tidak memilih pada masyarakat individual dipengaruhi oleh faktor lokasi, informasi dan penilaian rasional, usia dan tahap siklus hidup, kelompok referensi (keluarga), gaya hidup, orientasi agama dan moral, serta keyakinan dan sikap. Sedangkan yang mempengaruhi perusahaan untuk memutuskan pilihannya ditentukan oleh faktor informasi dan penilaian rasional, keyakinan dan sikap, peran dan status, serta iklan dan harga, berturut dari yang dominan ke yang kurang dominan. (Triyuwono dkk., 2000: 26)

Kalau dianalisis dari hasil kesimpulan di atas, dapat dilihat bahwa faktor informasi dan penilaian rasional menduduki posisi yang paling dominan untuk memilih atau tidak memilih bank syariah, bukan disebabkan kekurangpercayaan masyarakat terhadap bank syariah. Untuk itu, penelitian tentang akuntabilitas dan kompetibilitas, sebagai salah satu indikator informasi dan penilaian rasional tentang bank syariah, perlu dilakukan untuk mempercepat informasi pada masyarakat luas. Disinilah letak urgensi penelitian ini. Apalagi, penelitian dalam hal ini, sejauh pengetahuan penulis, belum pernah dilakukan sebelumnya.

\section{Tinjauan Teoritis}

\section{Tentang Prinsip Dasar dan Karakteristik Ekonomi Islam}

Ekonomi Islam, prinsip dasarnya dari al-Qur'an dan al-Hadits, tetapi proses wujudnya bersifat dinamis. Artinya, tidak memiliki hukum statis dan tidak pula memuat semua perincian hukumnya. Sistem ekonomi Islam semata-mata hanya menetapkan 
kerangka dan prinsip-prinsip dasar. Sementara itu, semua rinciannya diserahkan kepada masyarakat yang akan mengambil kebijaksanaannya sesuai dengan keadaan yang selalu berubah dan sesuai dengan kondisi zaman.

Latar belakang filosofis seperti ini dapat disimpulkan dalam beberapa prinsip universialisme Islam, seperti Kewakilan Manusia (Istikhlaf), tidak berbahaya dan tidak membahayakan (la dlarara wa la dlirar), Usaha dan Imbalan Jasa, Mengambil keuntungan melalui saham (al-ghanamu bil-gharam) (al-Anshori dkk., 1993).

Prinsip-prinsip ekonomi Islam juga secara singkat diungkapkan oleh Chapra (1995: 201) yang menyatakan :

"Islam is a universal faith which is simple and easy to understand and rationalise. It is based on three fundamental principles which are tawhid (unity), khilafah (vicegerency), and 'adalah (justice)."

Qardlawi (1997) dalam hal ini menggunakan istilah karakteristik (ciri khas) ekonomi Islam. Karakteristik itu antara lain bahwa ekonomi Islam merupakan ekonomi Ilahiah, dimana setiap kegiatan ekonomi yang dilakukan oleh pelaku ekonomi titik tolaknya bersumber dari Allah, tujuan hakikinya mencari ridha Allah, dan cara-cara yang dilakukannya tidak bertentangan dengan syariah Allah. Jika boleh diistilahkan, bahwa ekonomi Ilahiah tiada lain adalah segala kegiatan dan aktivitas ekonomi yang berorientasi pada Allah (God oriented).

Selain itu, hal yang membedakan antara sistem ekonomi Islam dengan sistem ekonomi maupun agama lain adalah bahwa antara ekonomi dan akhlak tidak pernah terpisah sama sekali, seperti halnya tidak pernah terpisah antara ilmu dan akhlak, antara politik dan akhlak, dan antara perang dan akhlak. Sebab itu, di dalam ekonomi Islam tidak mengenal apa yang disebut dengan tujuan menghalalkan segala cara, sehingga persoalan akhlak diabaikan begitu saja.

Menghargai kemanusiaan manusia adalah bagian dari prinsip Ilahiah yang telah memuliakan manusia dan menjadikannya sebagai khalifah-Nya di muka bumi ini. Sebagaimana pula "orientasi Ilahiah" merupakan bagian yang sangat fundamental dalam fitrah manusia, dan setiap orang dilahirkan dalam kondisi fitrah ini. Karena itu, ekonomi Islam juga berkarakteristik ekonomi kemanusiaan. Sebab itu, ruh sistem Islam adalah pertengahan yang adil, yang dengannya Allah menjadikan ciri khas umat ini (QS 12:143). 
Ciri khas pertengahan ini, tercermin dalam keseimbangan yang adil yang ditegakkannya dalam berbagai "pasangan" lainnya: dunia dan akhirat, jasmani dan ruhani, akal dan ruhani, idealisme dan realisme, "polisi" iman dan polisi penguasa dan pasangan-pasangan lainnya yang sudah sangat terkenal.

Tampaklah di sini, bahwa prinsip maupun karakteristik ekonomi Islam bila menjadi pijakan berfikir para pelaku ekonomi, akan dapat membimbing dan mengarahkannya pada visi, misi dan tujuan yang mulia dimana didalamnya mengandung unsur kemurnian niat (al-ikhlash), kemakmuran dan kesejahteraan umum/sosial, keadilan antara hak dan kewajiban serta mensyaratkan kegiatan yang berdasarkan pada prinsip perwakilan manusia sebagai khalifah di muka bumi.

\section{Tentang Kompetibilitas Bank Berdasarkan Syariah Islam}

Mengenai bank berdasarkan syariah Islam (Bank Islam), menurut Azis (1992:1), adalah lembaga perbankan yang menggunakan sistem dan operasinya berdasarkan syariah Islam. Ini berarti operasi perbankan mengikuti tata cara berusaha maupun perjanjian berusaha berdasarkan al-Qur'an dan al-Hadits Muhammad s.a.w, dan bukan tata cara dan perjanjian berusaha yang bukan dituntun oleh al-Qur'an dan Sunnah Rasul Muhammad s.a.w. Dalam operasinya Bank Islam menggunakan sistem bagi hasil dan imbalan lainnya yang sesuai dengan syariah Islam.

Mannan (1994:168-9) menyatakan bahwa mekanisme perbankan Islami yang berdasarkan prinsip mitra usaha adalah bebas bunga. Karena itu soal membayarkan bunga kepada para depositor atau pembebanan suatu bunga dari para klien tidak timbul.

Secara lebih rinci, al-Anshori dkk. (1993) mengemukakan mengenai ciri-ciri dan formula Bank Islam yang mempunyai pengaruh langsung terhadap operasional, baik dari segi investasi dan jenisnya, sumber-sumber dana dan jenisnya atau tanggung jawab bank terhadap nasabah. Ciri-ciri dasar ini dapat tercermin dalam bermacam fungsinya, seperti melaksanakan fungsi bank dagang (commercial banking), bank bisnis (business banking), bank investasi (investment banking), dan bank pembangunan (development banking). Maka operasionalnya tidak terbatas pada jangka pendek seperti bank dagang atau jangka menengah dan panjang seperti bank-bank non-dagang, tetapi meliputi jangka pendek, menengah dan panjang yang tercermin pada kerangka sumber dan penggunaan dananya. 
Bank Islam juga tidak melakukan transaksi dengan mengambil atau memberikan bunga-rente nyata atau tersembunyi; langsung atau tidak langsung, ditentukan sebelumnya atau sesudahnya; bergerak atau tidak bergerak berdasarkan atas tanggung jawabnya terhadap hukum syariah Islam. Bahkan, ia tidak memberikan pinjaman uang akan tetapi memberikan suplai bahan; berarti bank Islam tidak menginvestasikan dananya dalam bentuk uang dan tidak berdagang dalam bentuk kredit.

Terakhir, Bank Islam dalam melakukan transaksi dengan nasabahnya, pemegang rekening investasi (investor) atau simpanan atau pemakai dana terkait dengan kontrak musyarakah atau mudharobah berdasarkan atas prinsip mudharobah dan musyarakah dalam untung rugi. Kontrak bank Islam dengan para nasabah bukanlah kontrak penghutang (debitor) dan pepiutang (creditor) seperti halnya pada bank konvensional.

Prinsip-prinsip tersebut, menurut Aziz (1992:37-8), merupakan salah satu keunggulan konseptual bank syariah. Bahkan, keunggulan tersebut ditambah dengan keuntungan profit nasabahnya, sebagai salah satu keuntungan bagi hasil, sekitar 7,1 \% dalam setiap bulannya (Media Akuntansi, 2000:13-4), suatu keuntungan profit yang tidak akan diperoleh dari lembaga keuangan manapun. Lebih dari itu, kata Aziz (1992:39), keuntungan itu dalam pandangan Islam bukan berorientasi pada keuntunga prifit tersebut, tetapi pada keuntungan ketengan jiwa setelah mengamalkan syariah yang diinginkan oleh setiap pemeluk agama yang salih.

\section{METODE PENELITIAN}

\section{Lokasi Penelitian}

Penelitian ini dilakukan di Bank Syariah "X" cabang Malang di jalan Nama Pahlawan X no.8 Malang.

\section{Cakupan Penelitian}

Penelitian ini mencakup penelitian dokumenter dan penelitian lapangan yang terdiri dari dua komponen, yaitu:

a. Komponen institusi, dalam hal ini Bank Syariah " $X$ " Cabang Malang..

b. Komponen masyarakat (nasabah) sebanyak 10 orang, yang terdiri dari 5 nasabah penabung dan 5 nasabah pengguna. 


\section{Jenis Penelitian}

Penelitian ini, seperti yang tercermin dalam judulnya, adalah penelitian yang menggunakan pendekatan case study, yaitu pendekatan yang bertujuan untuk mempertahankan keutuhan (wholeness) dari obyek (Jacob Vreden Bregh, 1987:34). Sekalipun penelitian ini tidak ditujukan untuk generalisasi atau pengujian hipotesa, sifat kualitatifnya tetap memungkinkan adanya verifikasi. Sebab, dalam penelitian ekonomi yang bersifat kualitatif, menurut Rangkuti (1997: 32), tidak menolak verifikasi sama sekali dan tidak bertentangan dengan metode kuantitatif. Pendekatan verifikatif ini dimaksudkan untuk meminimalisir kemungkinan rendahnya reliabilitas yang sering terjadi dalam penelitian Studi Kasus.

\section{Perumusan Kategori}

Untuk kepentingan verifikasi ini, peneliti terlebih dahulu menentukan kategorisasikategorisasi. Sebab, bagian yang terpenting dari riset kualitatif-verifikatif, masih dalam pandangan Rangkuti (1997:32), adalah perumusan kategori-kategori yang disesuaikan dengan data. Indikator tersebut adalah (lihat gambar 1 ).

Dari gambar 1, menjelaskan beberapa kategori yang digunakan dalam penelitian rasional ini, yaitu:

a. Peningkatan kualitas dan kuantitas sosial ekonomi masyarakat; Perkembangan Usaha dan Permodalan Nasabah, baik perseorangan maupun badan usaha.

b. Manajemen Operasional Bank Syariah "X" Cabang Malang; Manajemen Pengerahan dan Pendayagunaan Dana, Laporan Keuangan, serta Penilaian Kesehatan bank syari'ah. Tingkat kesehatan ini dilihat dari dua sisi yaitu kualitatif dan kuantitatif. Dari sisi kualitatif bisa dilihat dari sejarah, pengelola, dan pemiliknya. Sisi kuantitatif dapat dilihat dari skore tertentu seperti rasio likuiditas, profitabilitas, dan permodalan, serta aspek manajemen. 


\section{Gambar 1}

\section{Penilaian Rasional Masyarakat Terhadap Bank Syariah dengan Menggunakan Analisis Akuntabilitas dan Kompetibilitas}
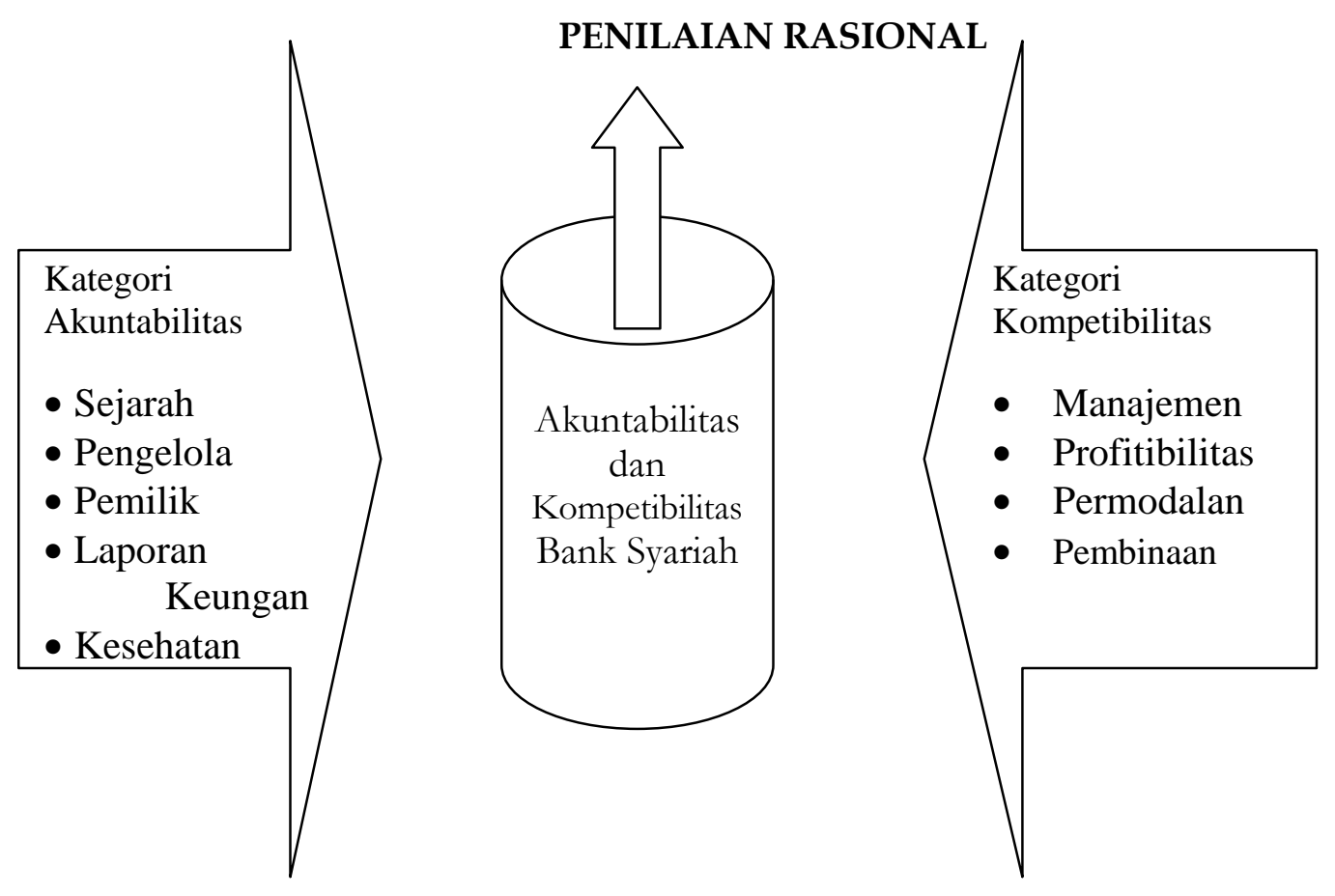

\section{Pengumpulan Data}

Secara garis besar pengumpulan data dalam penelitian ini berupa data sekunder dan data primer. Data sekunder didapatkan dari berbagai literatur yang mendiskusikan persoalan bank syariah, buku panduan penyelenggaraan bank syariah, majalah, surat kabar maupun laporanlaporan hasil penelitian. Sedangkan data primer bersumberkan dari pengurus dan dokumendokumen laporan keuangan Bank Syariah "X" Cabang Malang dan nasabah (peminjam) Bank Syariah " $X$ " Cabang Malang, baik usaha personal maupun badan usaha.

\section{Teknik Analisis Data}

Dalam penelitian ini, peneliti melakukan pengkajian konsep bank syariah dari berbagai literatur, baik yang menyangkut nilai-nilai normatif maupun berbagai teori dasar manajemen moderen, sekaligus mengkonformasikan secara nyata di lapangan. Oleh sebab itu, alat analisis 
yang digunakan adalah Content Analysis (analisis isi) dan Symbolic Interactionism (interaksionisme simbolik).

Analisis isi, menurut Kerlinger (1973: 525) adalah" a method of studying and analyzing commucatious in a systematic, objective and quantitative manner to measure variable." Jadi, analisis isi merupakan suatu tehnik penelitian untuk membuat inferensi-inferensi yang dapat ditiru (replicable) dan benar (sahih) dengan memperhatikan konteksnya. Berelson, seperti dirujuk Krippendorff, mendefinisikannya sebagai tehnik penelitian untuk mendeskripsikan secara obyektif, sistematik dan kuantitatif isi komunikasi yang tampak (manifest). Lebih lanjut, Krippendorff (1991:16-17) menuturkan bahwa secara intuitif, analisis isi dapat dikarakterisasikan sebagai metode penelitian makna simbolik.

Gambar 2

Disain Analisis Isi untuk Membandingkan Berbagai Metode yang berbeda

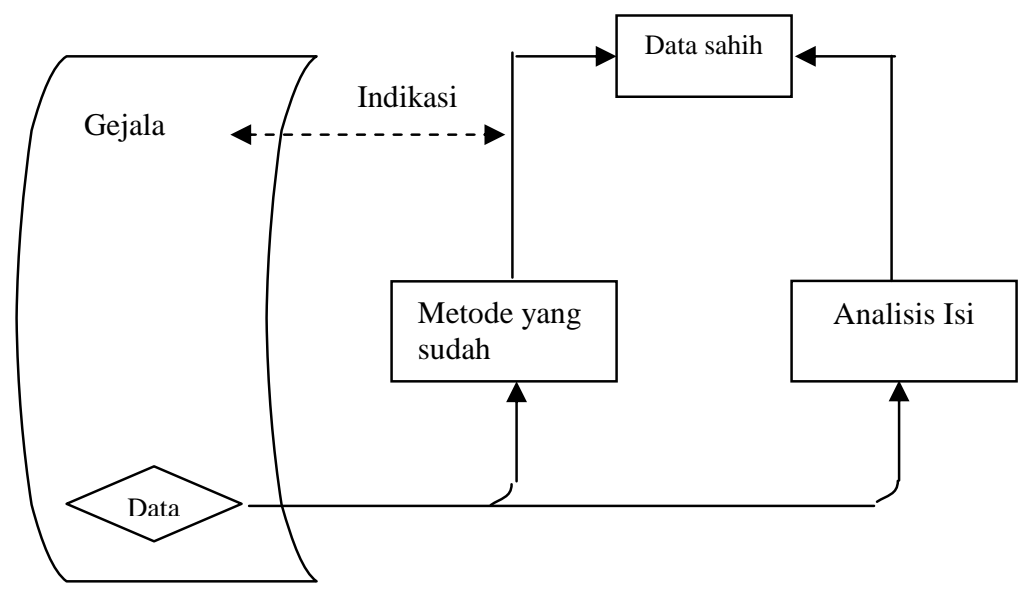

Oleh sebab itu, dalam hal ini peneliti memperhatikan makna tersebut dengan menggunakan perspektif mekanisme, psikologisme dan interaksionisme (Fisher: 1986). Disamping itu, peneliti juga menganalisis makna ini dengan tetap memperhatikan makna asli dan sekunder (tsanawi) sebab, kata al Syatibiy, setiap bahasa selalu mempunyai dua makna tersebut (al-Syatibiy, 1973: 85). Pesan-pesan rangkaian desain analisis isi meliputi beberapa langkah, yaitu: pembentukan data, reduksi data, penarikan inferensi, dan analisis yang membantu analisis isi melakukan validasi langsung, pengujian kesesuaian hasilnya dengan metode-metode lain seperti gambar 2 di atas.

Sedangkan untuk mendapatkan data secara empiris di lapangan, disamping peneliti menggunakan metode pengumpulan data dengan menggunakan questioner, interview dan 
observasi, peneliti juga menggunakan pendekatan psikologi-sosial dari perspektif interaksionisme simbolik yang diungkapkan Blumer sebagai sebuah perspektif yang mempunyai premis dasar sebagai berikut:

[1]... manusia bertindak terhadap sebuah objek atas dasar makna yang dimiliki oleh objek tersebut

[2].... makna dari objek tersebut diperoleh dari, atau berasal dari, interaksi sosial.

[3]... makna tersebut dihandel dan dimodifikasi melalui proses interpretasi (Triyuwono, 1998: 12)

Berkenaan dengan interaksionisme simbolik ini pula Blumer mengatakan lebih jauh bahwa:

Interaksionisme simbolik adalah pendekatan yang "turun ke bumi" (down-toearth approach) yang digunakan untuk studi ilmiah tentang kehidupan dan perilaku manusia. Jika ia ingin mempelajari perilaku kehidupan agama, maka ia akan turun langsung ke dalam kehidupan agama dan mengobservasinya dengan hati-hati. Jika ia ingin mempelajari gerakan sosial, maka ia akan menelusuri karir, sejarah dan gerakan pengalaman hidup yang sebenarnya dengan hati-hati (Blumer, 1969: 47).

Analisis isi dan interaksionisme simbolik ini dipergunakan dalam menganalisis dokumen dan hasil data interview yang diperoleh melalui peroses interaksi dengan informan (responden).

\section{PAPARAN DATA DAN TEMUAN PENELITIAN}

1. Faktor-faktor yang mendukung kompetibilitas bank syariah dalam meningkatkan kualitas dan kuantitas kehidupan sosial ekonomi masyarakat

Untuk mendukung tingkat kompetabilitas bank syariah " $X$ " Malang mulai tahun 2006 dilakukan dengan berbagai kerjasama kemitraan strategis dalam mendukung bisnis, melalui :

a. Kerjasama Pembiayaan

b. Kerjasama Pengembangan Usaha dan Service

c. Kerjasama Pendukung Usaha

2. Faktor-faktor yang mendukung penilaian akuntabilitas bank syariah dalam manajemen dan pengolahan dana, pengumpulan modal dan pemanfaatan dana. 
Untuk mengukur tingkat akuntabilitas bank syariah dalam manajemen dan pengolahan dana, pengumpulan modal dan pemanfaatan dana bisa diukur dari kinerja dan kesehatan Bank .melalui :

a. Rasio Likuiditas

Likuiditas bank yaitu kemampuan bank untuk memenuhi segala kewajiban jangka pendeknya dengan mengandalkan kredit (pembiayaan) yang diberikan. Berdasarkan SK.Dir.BI No.30 Th.1997 bab II pasal 11 penilaian ini didasrkan pada :

1). Rasio jumlah kewajiban bersih terhadap aktiva lancer atau serig disebut dengan Cash rasio.

2). Rasio LDR (Loan Deposit Ratio) dihitung dari kredit yang diberikan terhadap dana yang diterima bank..

Tabel 2.

Komponen Likuiditas

Per Desember 2005 dan 2006

(dalam ribuan)

\begin{tabular}{|c|l|r|r|}
\hline No & \multicolumn{1}{|c|}{ Komponen } & 2005 & \multicolumn{1}{|c|}{2006} \\
\hline 1 & Kewajiban Bersih antar bank & 2.792 .336 & 4.700 .127 \\
\hline 2 & Aktiva Lancar & 18.536 .661 & 25.929 .743 \\
\hline 3 & Pembiayaan & 37.786 .591 & 46.402 .001 \\
\hline 4 & Dana yang diterima & 98.878 .301 & 105.171 .563 \\
\hline
\end{tabular}

Sumber : Laporan keuangan Tahunan

\section{a) Cash Rasio}

kewajiban bersih antar bank

Cash Rasio = ----------------------------- x 100 \%

Aktiva lancar

Tahun 2005

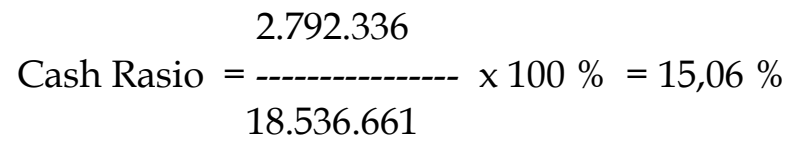

Tahun 2006

Cash Rasio $=\frac{4.700 .127}{25.929 .743} \times 100 \%=18,12 \%$

b) Rasio LDR
Total Pembiayaan
LDR = 
Tahun 2005

$$
\text { LDR }=\frac{37.786 .591}{98.878 .301} \times 100 \%=39 \%
$$

Tahun 2006

$$
\text { LDR }=\frac{46.402 .001}{105.171 .563} \times 100 \%=44,12 \%
$$

\section{b. Rasio Profitabilias}

Rasio ini digunakan untuk mengetahui laba (earning) yang diperoleh bank dalam setiap periode. Berdasarkan SK Dir.BI No.30 Th. 1997 bab II pasal 10, penilaian didasarkan profitabilias suatu bank yang diukur berdasarkan rasio :

1) Rasio sebelum pajak terhadap total asset (ROA)

2) Rasio beban operasional terhadap pendapatan operasional (BOPO)

Tabel 3

Komponen Profitabilitas

Per Desember 2005 dan 2006

(dalam ribuan)

\begin{tabular}{|c|l|r|r|}
\hline No & \multicolumn{1}{|c|}{ Komponen } & \multicolumn{1}{c|}{2005} & \multicolumn{1}{c|}{2006} \\
\hline 1 & Laba sebelum pajak & 2.508 .468 & 899.760 \\
\hline 2 & Total Aktiva & 125.455 .990 & 131.246 .087 \\
\hline 3 & Beban Operasional & 2.743 .099 & 3.323 .403 \\
\hline 4 & Pendapatan Operasional & 1.652 .996 & 2.072 .600 \\
\hline
\end{tabular}

Sumber : Laporan keuangan Tahunan

a) $\mathrm{ROA}$

$$
\text { ROA = } \frac{\text { Laba sebelum pajak }}{\text { Total Aktiva }} \times 100 \%
$$

Tahun 2005

$$
\text { ROA }=\frac{2.508 .468}{125.455 .990} \times 100 \%=1,99 \%
$$

Tahun 2006

$$
\text { ROA = } \frac{899.760}{131.246 .087} \times 100 \%=0,77 \%
$$


b) $\mathrm{BOPO}$

$$
\text { BOPO }=\frac{\text { Beban Operasional }}{\text { Pendapatan Operasional }} \times 100 \%
$$

Tahun 2005

$$
\mathrm{BOPO}=\frac{2.743 .099}{1.652 .996} \times 100 \%=84,75 \%
$$

Tahun 2006

$$
\text { BОРО }=\frac{3.323 .403}{2.072 .600} \times 100 \%=95,01 \%
$$

c. Rasio Permodalan

Berdasarkan SK Dir.BI No.30 tahun 1997 bab II pasal 7, penilaian berdaarkan rasio permodalan yang dimiliki oleh suatu bank. Adapun penilaiannya dengan menggunakan rasio CAR (Capital Adequacy Ratio), yaitu untuk mengukur kecukupan modal guna menutupi kemungkinan kegagalan pemberian kredit (pembiayaan). Penilaiannya dilakukan dengan membandingkan modal terhadap aktiva tertimbang menurut resiko (ATMR).

Tabel 4

Perhitungan Kewajiban Penyediaan Modal Minimum

Per Desember 2005 dan 2006

(dalam ribuan)

\begin{tabular}{|c|l|r|r|}
\hline No & \multicolumn{1}{|c|}{ Komponen } & \multicolumn{1}{|c|}{2005} & \multicolumn{1}{|c|}{2006} \\
\hline 1 & Modal & 5.704 .128 & 9.566 .409 \\
& a. Modal Inti & 3.192 .754 & 3.055 .135 \\
& b. Modal Pelengkap & 8.896 .882 & 12.621 .544 \\
\hline 2 & Total Modal Inti dan Pelengkap & $(527.641)$ & $(605.937)$ \\
\hline 3 & Penyertaan pihak lain & 8.369 .241 & 12.015 .607 \\
\hline 4 & Total Modal & 52.521 .110 & 66.171 .777 \\
\hline
\end{tabular}

Sumber : Laporan keuangan Tahunan (diolah) 


$$
\mathrm{CAR}=\frac{\text { Modal }}{\text { ATMR }} \times 100 \%
$$

Tahun 2005

Tahun 2006

$$
\begin{aligned}
& \text { CAR }=\frac{8.896 .882}{-0.521 .110} \times 100 \% \\
& =16,94 \%
\end{aligned}
$$

$$
\begin{aligned}
& \text { CAR }=\frac{12.015 .607}{66.171 .777} \times 100 \% \\
& =19,07 \%
\end{aligned}
$$

d. Aspek Manajemen

berdasarkan Sk. Dir BI No.30 1997 bab II pasal 9 penilaian berdasarkan pada pernyataan bank terhadap 100 pertanyaan aspek manajemen yang disusun dan diajukan oleh Bank Indonesia. Penilaian manajemen untuk bank umum non devisa didasarkan pada 85 aspek, sedangkan 15 aspek lainnya berkaitan dengan kegiatan usaha bank umum devisa.

Aspek-aspek tersebut dalam Bank Syariah X Malang merupakan startegi untuk mempertahankan Non Performing Financing (NPF), yaitu dengan cara menyusun account strategi secara seksama. Hasilnya NPF dapat ditekan hingga di bawah $5 \%$, taitu sebesar 4,64 \% netto dia akhir tahun 2006. Bank juga telah mengalokasikan cadangan PPAP sebesar 101,15\% terhadap PAP yang wajib dibentuk.

\section{PEMBAHASAN}

1. Faktor-faktor yang mendukung kompetibilitas bank syariah dalam meningkatkan kualitas dan kuantitas kehidupan sosial ekonomi masyarakat

a. Kerjasama Pembiayaan

Pada akhir tahun 2006 dari sisi pembiayaan menargetkan pada segmen non korporasi yaitu pembiayaan kepada sector usaha mikro, kecil dan menengah (UMKM) yang meningkat dari 37 \% menjadi 42 \% pada tahun 2007. seperti yang diungkap oleh Pimpinan Cabang Bapak Ramelan

Sektor UMKM merupakan sector yang menarik untuk dijadikan target bisnis, dimana sector ini relative mampu menghadapi guncangan, yang terbukti 
keandalannya pada saat badai krisis menerpa perekonomian Indonesia (wawancara 24 Agustus 2007).

Kerjasama pembiayaan yang dilakukan melalui BPR dan BMT yang ada di Malang seperti BPRS BUmi Rinjani. Seperti yang diungkap oleh Bapak Abd.Rohim,MA wakil direktur BPRS Bumi Rinjani selaku mitra usaha dalam wawancara dengan peneliti bahwa :

Dukungan pembiayaan BPRS kami melalui Bank syariah " $X$ " ini kita gunakan sebgai tambahan modal operasional unit BPRS kami dalam mendanai kebutuhan nasabah kami di Batu untuk pembiayaan pembelian handphone di mana kami dapat selisih margin, sehingga kami merasa terbantu atas adanya bank syariah ini (wawancara tanggal 6 Agustus 2007).

\section{b. Kerjasama Pengembangan Usaha dan Service}

Untuk peningkatan pelayanan usaha dilakukan juga dengan unit-unit usaha pemerintah maupun swasta seperti dengan KPRI UIN Malang dalam rangka percepatan haji, seperti hasil wawancara kami dengan ketua KPRI UIN Malang Bapak Drs.H. Sudiyono, yang menyatakan :

Untuk percepatan jamaah haji dilingkungan kami sudah empat tahunan ini kami mengadakan arisan haji (jironah) dengan anggota sebanyak sepuluh pasang dan telah memberangkatkan dua pasang pada tahun 2005, akan tetapi dengan kerjasama dengan Bank Syariah " $X$ " ini untuk tahun ini sebetulnya bisa memberangkatkan yang sisanya depan pasang akan tetapi yang masuk kuota ada tiga pasang, yang dibiayai dari dana mudharobah, yang sya sebut dengan program percepatan haji, kalau tidak melalui bank syariah bisa semua berangkat hingga tahun 2015, tapi dengan adanya kerjasama dengan Bank syariah dapat dipercepat hingga tahun 2008 (wawancara tanggal 20 Agustus 2007).

\section{c. Kerjasama Pendukung Usaha}

dalam rangka mendukung usaha bank syariah telah melakukan upaya-upaya edukasi dan pembinaan sumber daya insani (SDI) seperti melakukan kerjasama dengan Fakultas Ekonomi UIN Malang mellaui dosen tamu mata kuliah di mata kuliah Perencanaan SDM pada tanggal 5 Juli 2007 yang langsung disampaikan oleh bapak Ramelan selaku pimpinan bank syariah "X" cabang Malang.

2. Faktor-faktor yang mendukung penilaian akuntabilitas bank syariah dalam manajemen dan pengolahan dana, pengumpulan modal dan pemanfaatan dana.

1. Rasio Likuiditas

Menurut Santoso (1995:91) rasio likuiditas digunakan untuk mengukur kemampuan bank dalam memenuhi kewajiban jangka pendeknya. Dalam hal ini factor yang sangat 
berpengaruh adalah instrument yang terdiri dari giro, tabungan, deposito, dan kewajiban segera dibayar .

Dari perhitungan likuiditas dapat diketahui bahwa cash rasio pada tahun 2005 15,06 \% naik menjadi 18,12\% pada tahun 2006 sehingga mempunyai predikat baik karena diatas batas minimum cash ratio yang ditetapkan oleh BI yaitu sebesar 4,05\%. Terjadinya kenaikan pada cash ratio karena bank dapat mengatasi kewajibannya dengan aktiva lancarnya, dimana pada tahun 2005 untuk setiap Rp. 1,00 kewajiban akan dijamin dengan aktiva lancar Rp. 15,06 jadi komposisinya 1 : 15, sedangkan pada tahun 2006 meningkat untuk Rp. 1,00 kewajiban akan dijamin dengan aktiva lancar Rp 18,12, jadi komposisinya $1: 18$.

Pada perhitungan LDR antara tahun 2005 ke tahun 2006 mengalami kenaikan. LDR pada tahun 2005 sebesar 39 \% sedangkan pada tahun 2006 mengalami kenaikan menjadi 44,12 \%, walaupun peningkatan prosentase LDR bukan berarti kebaikan akan tetapi merupakan kondisi yang kurang baik, akan tetapi pada bank syariah " $X$ " ini masih dalam predikat sehat karena masih berada di bawah ketentuan Bank Indonesia yaitu 93,52 \%. Untuk LDR dinyatakan bahwa semakin kecil LDR adalah semakinbaik, karena angka LDR tinggi menunjukkan bahwa dana deposito masyarakat yang ditanamkan pada pinjaman semakin besar. Padahal pinjaman bukanlah merupakan aktiva yang likuid, yang mana pinjaman dengan aktiva yang diterima haruslah seimbang.

2. Rasio Profitabilitas

Pada rasio profitabilitas ini factor yang sangat berpengaruh adalah pendapatan dan beban, karena tingkat keuntungan merupakan selisih dari seluruh pendapatan dan beban suatu periode tertentu yang diungkapkan dalam laporan laba rugi. Tujuan penilaian rasio profitabilitas adalah untuk mengetahui kemampuan bank dalam menghasilakn laba melalui operasional bank (Abdullah, 2003: 112). Untuk analisis profitabilitas peneliti menggunakan ROA dan BOPO.

Dari perhitungan ROA tampak ada penurunan antara tahun 2005 ke 2006, di mana pada tahun 2005 ROA sebesar 1,99 \% sedangkan pada tahun 2006 menjadi 0,77\% yang mengakibatkan menjadi kurang sehat.

Dari perhitungan BOPO mengalami kenaikan dari tahun 2005 sebesar 84,75\% menjadi pada tahun 2006 sebesar 95,01 \%. Terjadinya kenaikan ini karena adanya kenaikan biaya operasional 
yang lebih besar dari pendapatan opearasional, hal ini juga terjadi pada rata-rata bank konvensional.

3. Rasio permodalan

Posisi permodalan sesuai criteria Bank Indonesia dari CAR minimal adalah $8 \%$ untuk dapat dikatakan sehat, sedangkan adalah 10 \% tentang bank berkinerja. Untuk bank syariah " $\mathrm{X}^{\text {" pada }}$ tahun 2005 16,94 \% tumbuh menjadi 19,07 \% pada tahun 2006, hal ini menurut Abdullah (2004:67) terdapat factor yang mempengaruhi yaitu : tingkat kualitas manajemen bank, tingkat kualitas yang dimiliki, tingkat kualitas dari asset, struktur deposito, tingkat kualitas dari system dan prosedurnya, tingkat kualitas dan karakter para pemilik saham, kapasitas untuk memenuhi kebutuhan jangka pendek maupun jangka panjang, riwayat pemupukan modal dan peraturan pembagian laba yang diperolehnya.

\section{SIMPULAN}

Kesimpulan yang dapat diambil adalah: (1) Faktor-faktor yang mendukung kompetibilitas bank syariah dalam meningkatkan kualitas dan kuantitas kehidupan sosial ekonomi masyarakat adalah: kerjasama pembiayaan, kerjasama pengembangan usaha dan service, dan kerjasama pendukung usaha melalui UMKM yang diharapkan mencapai $42 \%$ pada tahun ini, (2) Faktorfaktor yang mendukung penilaian akuntabilitas bank syariah dalam manajemen dan pengolahan dana, pengumpulan modal dan pemanfaatan dana dapat dilihat dari aspek likuiditas yang mengalami kenaikan cash rasio pada tahun 2005 15,06 \% naik menjadi 18,12\% pada tahun 2006 sehingga mempunyai predikat baik karena diatas batas minimum cash ratio yang ditetapkan oleh BI yaitu sebesar 4,05 \%, sedangkan LDR 44,12 \%, masih dalam predikat sehat karena masih berada di bawah ketentuan Bank Indonesia yaitu 93,52 \%. Untuk aspek profitabilitas ROA tampak ada penurunan antara tahun 2005 ke 2006, di mana pada tahun 2005 ROA sebesar 1,99 \% sedangkan pada tahun 2006 menjadi 0,77\%, untuk BOPO mengalami kenaikan dari tahun 2005 sebesar 84,75\% menjadi pada tahun 2006 sebesar 95,01 \%, untuk aspek permodalan dikatakan sehat dan berkinerja ,karena CAR di atas $10 \%$ yang pada tahun 2005 $16,94 \%$ tumbuh menjadi $19,07 \%$. 


\section{DAFTAR PUSTAKA}

Abdullah,M.Faisal. 2003. Manajemen Perbankan (Teknik Analisis Kinerja) UMM Pres,Malang al-Anshori, Mahmoud, Ismail Hasan, Samir Mutawali (1993). Perbankan Islam, Sejarah, Prinsip dan Operasional. Jakarta: Penerbit Minaret.

al-Harran, Saad Abdul Sattar. 1996. Islamic Finance, Partnership financing. . Malaysia: Pelanduk Publications.

al-Maududi, Abul A'la. 1998. Problema-Problema Ekonomi dan Pemecahannya Dalam Islam. Bandung: PT. Al-Ma'arif.

al-Syatibiy, Abu Ishaq. 1973. al-Muwafaqat fi Ushul al-Syari'ah. Beirut: Dar al-Ma'rifah.

Altman and Haldeman, Robert G, N. Narayana, P. 1977. "Zeta Analysis, New Model to Identity Bankruptcy Risk of Corporation." Journal of Bank and Finance. Holland: North Holland Publishing Company.

Aziz, Amin. 1992. Mengembangkan Bank Islam di Indonesia. Jakarta: Penerbit Bangkit.

Bank Indonesia. 2000. Himpunan Ketentuan Perbankan Indonesia 2000

Chapra, M. Umer. 1992. Islam and The Economic Challenge. Malaysia: The International Institute of Islamic Thought.

Chapra, M. Umer. 1995. Towards a Just Monetary System: A Discussion of Money, Dunking and onetary Policy in The Light of Islamic Teaching. Malaysia: The International Institute of Islamic Thought.

Fisher, B.A. 1986. Perspectives on Human Communication. Edisi Indonesia. Bandung; Remaja Rosda Karya.

Horne Van, James C. 1986. Financial Management and Policy. Seventh Edition USA: Prentice Hall.

Husnan, Suad. 1985. Manajemen Keuangan, Teori dan Terapan. Jilid I. Edisi I. Yogyakarta: BPFE.

Juwita, Himmiyatul Amanah Jiwa. 1997. Analisis Kinerja Keuangan Sebelum dan Sesudah Pelaksanaan Akuisisi Pada Sektor Perbankan di Indonesia. (Tesis) Malang: Program Pasca Sarjana Universitas Brawijaya.

Kerlinger, Fred N. 1973. Foundation of Behavioral Research. New York: Halt, Rivehart and Winston, Inc.

Kotler, Philip. 1994. Manajemen Pemasaran (Edisi Indonesia). Jakarta: Salemba Empat/PrenticeHall.

Krippendorff, Klaus. 1991. Analisis Isi: Pengantar Teori dan Metodologi. Jakarta: Rajawali Pers.

Mannan, Abd. 1970. Islamic Economics, Theory and Practise. Lahore: Sh. Muhammad Ashraf and Sons.

Perwataatmadja, Karnaen A. 1996. Alternatif Pemecahan Masalah Ekonomi Ummat dan Kemungkinan Mengembangkannya. (Diktat). 
Qardlawi, Yusuf. 1991. Bank Tanpa Bunga. Jakarta: Usamah Press.

Qardlawi, Yusuf .1991. Hukum Zakat. Bogor: Litera Antar Nusa.

Qardlawi, Yusuf. 1995. Peran Nilai dan Moral Dalam Perekonomian Islam. Jakarta: Robbani Press.

Rangkuti, Freddy. 1997. Riset Pemasaran. Jakarta: PT. Gramedia Pustaka Utama.

Sabiq, Sayyid. 1990. Fikih Sunnah , Jilid 3. Bandung: al-Ma'arif.

Santoso, Ruddy Tri. 1995. Prinsip Dasar Akuntansi Perbankan. Ed. I. Yogyakarta: Andi Offset..

Sudarman MA, Z. 1992. “BMI: Sebuah Paket Perekonomian Untuk Umat Islam Indonesia”, Al Muslimun No 267/Th XXIII (39) Bangil.

Sulaiman, Thahir Abdul Muhsin. 1985. Menanggulangi Krisis Ekonomi Secara Islam. Bandung: PT Al Ma'arif.

Triyuwono, Iwan.1998. Manajemen Profesional, Sistem Pengendalian Intern dan Accountability: Upaya Mengaktualisasi dan Meningkatkan Potensi Lazis. Malang: Fakultas Ekonomi Brawijaya.

Triyuwono, Iwan dkk. 2000. Potensi Prefensi, dan Perilaku Masyarakat terhadap Bank Syariah di Wilayah Jawa Timur. Malang: CBIES FE Unibraw.

Wibisana, M. Jusuf dkk. 1999 Studi Pendahuluan Persepsi Masyarakat tentang Bank Perkreditan Rakyat Syariah. Malang: CBIES FE Unibraw. 